\title{
GANGGUAN - GANGGUAN DALAM PSIKOLOGI SOSIAL DAN KEAGAMAAN
}

\author{
Replita \\ Lecturer of Da'wah and Communication Sciences at IAIN Padangsidimpuan \\ Jl. T. Rijal Nurdin Km.4,5 Sihitang Padangsidimpuan 22733 \\ Email: replita@yahoo.co.id
}

\begin{abstract}
In many people's lives all disturbances that occurred, which can inhibit the activities to be carried out. Every human being will certainly be impaired social, but the way everyone in receiving interference can be different from one with another. It depends on the level of education and experience as well as human faith that the social disturbed, and in general, every human being no one wants to be the existence of the disorder, even some people who are trying to avoid the interference. Social disruption that occurs is a social condition that needs to be changed and improved, so it depends on the man in question was the one who would bring the direction where the change occurs. Usually people who have the experience that many will certainly have a solution about how to cope with the social disruption.
\end{abstract}

Keywords: Disorders, Social, and Religious

\begin{abstract}
Abstrak
Dalam kehidupan masyarakat banyak sekali gangguan-gangguan yang terjadi, sehingga dapat menghambat kegiatan yang akan dilakukan. Setiap manusia tentunya akan mengalami gangguan sosial, tetapi cara setiap orang dalam menerima gangguan dapat berbeda antara satu dengan lainnya. Hal ini tergantung pada tingkat pendidikan dan pengalaman serta keimanan manusia yang mengalami gangguan sosial tersebut, dan pada umumnya setiap manusia tidak ada yang menginginkan akan adanya gangguan tersebut, bahkan tidak sedikit manusia yang berusaha untuk menghindari adanya gangguan tersebut. Gangguan sosial yang terjadi merupakan kondisi sosial yang perlu diubah dan diperbaiki, sehingga tergantung pada manusia yang bersangkutanlah yang akan membawa kearah mana perubahan itu dilakukan. Biasanya orang yang memiliki pengalaman yang banyak tentunya akan memiliki solusi yang banyak tentang cara mengatasi gangguan sosial tersebut.
\end{abstract}

Kata Kunci: Gangguan, Sosial, dan Keagamaan.

\section{PENDAHULUAN}

Masalah sosial merupakan kondisi yang tidak diinginkan karena mengandung unsur-unsur yang dianggap merugikan baik dari segi fisik maupun non fisik bagi kehidupan masyarakat. Lebih dari itu, dalam kondisi sosial ini sering juga terjadi pelanggaran dan penyimpangan terhadap nilai, norma dan standart sosial tertentu. Oleh sebab itu masalah sosial merupakan kondisi yang perlu diubah dan diperbaiki. 
Masalah kondisi sosial dapat berupa kondisi kehidupa masyarakat yang mengalami disintegrasi. Dalam kondisi ini hubungan masyarakat terpecah dan tidak menunjukkan hubungan yang harmonis, atau dapat pula berupa tidak berungsinya berbagai lembaga yang ada, akibatnya akan mengganggu dan menghambat pelaksanaan pembangunan masyarakat itu sendiri.

Manusia baik sebagai individu, maupun sebagai bagian dari kelompok pasti akan melakukan interaksi, baik antar sesama maupun dengan lingkungan. Di dalam melakukan interaksi, banyak sekali yang diharapkan dan yang diinginkan oleh seseorang, akan tetapi tidak semua yang diinginkan itu dapat tercapai. Akibat harapan sering tidak dapat mencapai suatu tujuan maka mengakibatkan munculnya masalah. Di dalam kehidupan manusia tidak dapat dihindarkan akan adanya gangguan atau masalah, mulai dari masalah yang kecil sampai kepada masalah yang besar. Hal ini ditegaskan Allah SWT dalam AlQur'an surat Al Syura' ayat 30 yang artinya: Dan apa saja musibah (masalah) yang menimpa kamu disebabkan oleh perbuatan tanganmu sendiri, dan Allah memaafkan sebagian besar ( dari kesalahan-kesalahanmu).

Kemudian pada surat lain Allah menegaskan dalam surat An - Nisa Ayat 147 yang artinya: apa gunanya bagi Allah menyiksa kamu, sedang kamu dalam keadaan bersyukur dan beriman. Dan Allah adalah Maha pembalas syukur lagi Maha mengetahui.

\section{PENGERTIAN DAN BENTUK-BENTUK GANGGUAN}

Gangguan sosial adalah sesuatu hal atau kejadian yang membuat langkah seseorang terhenti atau tersendat untuk beberapa waktu dan harus menyelesaikan hal tersebut sebelum mampu untuk meneruskan apa yang terjadinya tersendat ${ }^{1}$. Jadi gangguan sosial membuat seseorang tehambat atau terhalangi untuk mencapai suatau tujuan. Adapun Jenis gangguan sosial dapat dikategorikan menjadi 4 faktor yakni ${ }^{2}$ :

1. Faktor Ekonomi: kemiskinan, pengangguran.

2. Faktor Budaya: perceraian, kenakalan remaja.

3. Faktor Biologis: penyakit menular, keracunan makanan,

4. Faktor Biologis: penyakit syaraf, aliran sesat.

Jadi gangguan - gangguan sosial itu banyak sekali, namun yang lebih banyak pengaruhnya yakni:

\section{Faktor ekonomi dan kemiskinan.}

Masalah kemiskinan merupakan masalah yang sangat banyak dihadapi Negaranegara yang berkembang, salah satunya adalah Negara Indonesia. Apabila diperhatikan dalam kondisi sekarang, dimana tidak sedikit orang yang terjerumus ke berbagai jenis

\footnotetext{
1 Aini Mahabbati, Gangguan Sosial,( Bandung: Angkasa, 2006), hlm. 115.

2 Ibid, hlm 98.
} 
kejahatan yang disebabkan oleh kemiskinan, seperti, seseorang yang jatuh pada lembah pelacuran, menjadi pembunuh, perampok, dan lain-lain. Jadi persoalan kemiskinan merupakan persoalan yang sangat manusiawi, dimana persoalan ini akan selalu ada dan selalu berhadapan dengan manusa. Manusia selalu dituntut untuk kreatif memecahkan atau meminimalisasi segala kekurangan yang sering dilakukan. Dalam hal ini Yusuf Qordhowi mengatakan bahwa kemiskinan kemungkinan basar dapat merusak ibadah, akhlak dan tingkah laku atau perbuatan, kehidupan rumah tangga serta kestabilan dan ketentraman masyarakat ${ }^{3}$. Kemiskinan ini dapat terjadi disebabkan karena beberapa faktor yakni faktor intern yaitu yang berasal dari diri sendiri, seperti etos kerja yang lemah, kurangnya kedisiplinan terhadap waktu dan pola kerja yang kurang professional, serta pemahaman yang keliru terhadap kehidupan duniawi yang dianggap hanya semetara saja, dan sebagainya. Faktor-faktor tersebut melemahkan produktivitas seseorang yang juga membuat rendahnya satatus social ekonominya di tengah masyarakat. Atau adanya pemahaman yang keliru terhadap kehidupan duniawi, dimana sebagian masyarakat menganggap bahwa dunia ini adalah sebagai suatu kejahatan dan malapetaka, dengan demikian menurut golongan ini bahwa segala kemewahan di dunia ini harus dihindari karena manusia dituntut hanya untuk sekedar memanfaatkan segala yang ada di alam ini yaitu hanya sekedar untuk mempertahankan hidup, tanpa diharuskan untuk berusaha mengembangkan apa yang telah ada di alam ini. Oleh kerena itu manusia banyak berangapan bahwa kemiskinan itu bukanlah malapetaka, dan bukanlah suatu permasalahan yang perlu dituntaskan golongan ini sering disebut dengan golongan yang sering mensucikan kemiskinan seperti orang yang zahid, para sufi, pendukung pertapaan. Menurut mereka kemiskinan bukanlah sesuatu yang harus dihindari tetapi mereka beranggapan bahwa kemiskinan adalah salah satu dari rahmat Allah yang dianugerahkan pada hambanya, agar hati hambanya tetap mengingat Allah.

Adapun yang merupakan penyebab kemiskinan dari faktor ekstern yaitu banyaknya terjadi korupsi, system ekonomi yang berorientasi kepada persaingan bebas dan terjadinya kapitalisme yang menguntungkan pemodal besar semata dan lain-lain yang bersifat struktural seperti pembangunan yang dititik beratkan pada pembangunan ekonomi dan kurang menekankan pembangunan administrasi dalam arti luas. Selain itu tidak adanya keadilan dan kesetia kawanan sosial. Sri Edi Swasono mengatakan bahwa sebahagian umat Islam tidak memiliki peluang yang adil untuk memperoleh sumber-sumber kekayaan yang ada di masyarakat ${ }^{4}$. Kebodohan, fatalisme dan lain-lain yang melanda umat Islam dapat diperbaiki bila orang-orang kaya menaruh perhatian pada institusi yang telah diperintahkan

\footnotetext{
${ }^{3}$ Syekh Muhammad Yusuf Al Qordhowi, Problema Kemiskinan Apa Konsep Islam, (Surabaya: Gema Insani Press, 1982), hlm, 61,

${ }^{4}$ Sri Edi Swasono, dkk, Kemiskinan dan Keadilan, Universitas Indonesia, ( Jakarta: Departemen Agama RI, 1989), hlm. 157.
} 
Islam seperti zakat, infaq, sedekah dan sebaginya. Orang-orang kaya dituntut untuk mendirikan lembaga-lembaga pendidikan, dan memberikan bantuan berupa beasiswa.

\section{Etos Kerja dan Disiplin Kerja yang Lemah}

Kemauan kerja merupakan fitrah dalam kejiwaan manusia, yang telah diputuskan sendiri melalui keinginan-keinginannya. Akan tetapi kenyataannya umat manusia banyak yang lalai dan malas dalam menjalankan aktivitasnya. Dalam hal ini pendapat Hardiman yang dikutip oleh Soetomo mengatakan bahwa akibat dari sifat malas dan kurangnya keterampilan serta rendahnya kemampuan untuk menanggapi persoalan di sekitarnya ${ }^{5}$.

Banyak yang tidak menyadari bahwa kemiskinannya adalah disebabkan oleh dirinya sendiri. Hal ini terjadi karena sikap, mental dan disiplin kerja belum berorientasi kepada nilai social budaya sebagai pandangan hidup yang bersumber dari ajaran agama, system kepercayaan, filsafat, adat istiadat dan seni. Seseorang yang tidak berhasil dalam menjalani kehidupan salah satunya adalah karena tidak berfungsinya etos kerja secara baik. Hal ini terjadi karena tidak ditopang dengan sikap mental dan disiplin yang baik. Etos kerja yang rendah dan adanya sifat malas, serta kurangnya kemampuan intelelektual membuat masyarakat menjadi kekurangan dalam pemenuhan kebutuhan hidup sehari-hari.

\section{Meningkatnya Angka Pengangguran Terdidik}

Masalah ketenagakerjaan dan kesempatan kerja merupakan suatu masalah mendesak dalam pembangunan pedesaan karena mencakup secara langsung upaya pencapaian trilogy pembangunan., Pengangguran terjadi karena adanya migrasi desa ke kota yang dikemukakan oleh Todaro yang dikutip oleh Sajoiyo, ddimana model tersebut memandang bahwa aliran perpindahan pnduduk dari desa ke kota menjadi salah Suatu penyebab masalah pengangguran di kota. Kemudian menurut Todaro pengangguran juga disebabkan oleh adanya pemusatan pembangunan di kota, serta macetnya sector-sektor pembangunan di desa ${ }^{6}$. Padahal pada sisi lain seseorang yang berimigrasi ke kota belum dapat dipastikan akan mendapat lapangan pekerjaan. Dengan kata lain seringkali, orang-orang melakukan urbanisasi tanpa pertimbangan secara psikologi .Namun isu utama terjadinya migrasi penduduk ke kota adalah karena dalam pengembangan wilayah yaitu pembangunan tidak dilaksanakan di seluruh wilayah pada waktu yang bersamaan, tetapi sering dipusatkan pada pembangunan kota dan sisanya baru untuk pembangunan desa.

Proses migrasi ke kota merupakan gejala umum yang terjadi baik di Negara yang sedang berkembang maupun di Negara yang sudah maju. Di Negara Indonesia proses urbanisasi sangat cepat perkembangannya. Hal ini perlu ditanggulangi dengan cara meningkatkan keberhasilan pembangunan di pedesaan, sehingga masyarakatnya tidak perlu

\footnotetext{
5 Soetomo, Masalah Sosial Dan Pembangunan, (Jakarta: Pustaka Jaya: 1995), hlm. 126.

${ }^{6}$ Prof. DR. Sajogyo, Pembangunan Daerah dan Pemberdayaan Masyarakat, (Jakarta: Bina Rena Pariwara: 1997), hlm.22.
} 
meninggalkan daerahnya.

Jadi masalah ini menjadi masalah yang cukup pelik dari masa ke masa. Dengan demikian akan merugikan perekonomian secara umum. Ada beberapa keugian jika masalah pengangguran tidak bisa diatasi yaitu: Pertama, kerugian social yang akan berdampak dan bekal yang cukup kecuali sekedar harapan dan keyakinan. Kedua kerugian ekonomi yang akan berdampk pada berkurangnya produksi.

Masalah pengangguran yang terdapat di perkotaan yang makin menumpuk seiring dengan masih rendahnya tingkat upah di Negara-negara berkembang, seperti di Indonesia. Terjadinya pengangguran terdidik di negara-negara berkembang telah menghasilkan berbagai dilema, dimana upaya yang dilakukan untuk memperluas fasilitas pendidikan guna pencapaian pemerataan hasil-hasil pendidikan ternyata tidak diiringi dengan peningkatan kualitas tamatannya. Efek ganda dari dilema di atas adalah semakin banyaknya pencari kerja berusia muda dan berpendidikan. Menurut Todaro yang dikutip Sajogyo, bahwa penyelesaian masalah pengangguran tidak semudah teorinya. Faktor kebijakan pemerintah untuk melakukan redribusi dan desentralisasi pembangunan menjadi kunci utama dalam menyelesaikan masalah pengangguran di kota - kota besar ${ }^{7}$. Namun Lewin memandang bahwa komponen utama dalam kebijakan tenaga kerja adalah dengan mengusulkan penyempitan jurang upah antara desa dan kota, yang kemudian diramalkannya mengurangi laju imigrasi dari desa ke kota, dimana menurutnya sektor pembangunan di desa juga dibangun. Dengan cara ini factor imigrasi dapat diperlemah, atau dengan cara melakukan pembagian tugas yaitu bagaimana sektor kota menghindari produksi komoditas yang dihasilkan di desa.

Kemudian relatif terbatasnya daya serap ekonomi terhadap perluasan pasar kerja sebagai akibat dari kondisi mikro ekonomi serta efek dari kompetisi mendapatkan pekerjaan. Menurut Elfindri, kompetisi yang semakin tinggi dalam memasuki pasar kerja telah menyebabkan mereka yang berpendidikan menengah memiliki daya saing yang lebih rendah bila dibandingkan dengan mereka yang berpendidikan tinggi. Sementara semakin terbatasnya daya serap pasar kerja serta seleksi yang semakin ketat yang dibarengi dengan laju pertumbuhan penawaran angkatan kerja wanita yang membuat pasar kerja semakin sempurna ${ }^{8}$.

Pemicu pengangguran di Indonesia mengikuti trend globalisasi, dimana pada saat ini lapangan pekerjaan sudah semakin menyempit, apalagi dengan adanya pasar bebas, baik menyangkut pasar jasa maupun pasar barang dan modal. Apalagi dengan adanya pemanfaatkan teknologi yang semakin canggih, sehingga mengurngi pemanfaatan tenaga manusia, dan akhirnya menyebabkan munculnya pengangguran.

Oleh karena itu masalah ketenaga kerjaan dan kesempatan kerja merupakan suatu

\footnotetext{
7 Ibid.hlm. 25 .

8 Prof. Dr. Elfindri, Ekonomi Ketenaga Kerjaan, ( Padang; Andalas University Press, 2004), hlm. 83.
} 
masalah mendesak dalam pembangunan baik di perkotaan maupun di pedesaan, karena mencakup secara langsung upaya pencapaian trilogi pembangunan, yang menyangkut: a). pemerataan pembangunan dan hasil-hasilnya, b).pertumbuhan ekonomi ysng tinggi, c). Terciptanya stabilitas yang dinamis. Perluasan lapangan kerja dapat menyerap pertambahan angkatan kerja baru dan mengurangi pengangguran.

\section{Sulitnya Tingkat Ketersediaan dan Penyebaran Kemudahan}

Kemudahan yang dimaksud adalah kemudahan bagi masyarakat dalam memenuhi kebutuhan hidup sehari-hari seperti pangan, sandang, papan, pelayanan pendidikan, kesehatan, kesempatan melakukan ibadah, rekreasi dan sebagainya, maupun kesempatan untuk memperolah bahan baku, bahan penolong, pemasaran dan perbankan).Tingkat kemudahan sudah mencakup pengertian aksesibilitas. Kemudahan dengan ciri-ciri seperti itu lebih banyak terdapat di kota-kota daripada di daerah-daerah pedesaan.di perkotaan tingkat kemudahan tinggi, maka orang akan datang ke kota membawa pengalaman serta modalnya.

\section{Adanya Beberapa Penyakit yang Dialami}

\section{Frustasi}

Frustasi adalah keadaan bathin seseorang, ketidakseimbangan dalam jiwa, suatu perasaan tidak puas karena dorongan yang tidak terpenuhi ( Frustation= kekecewaan) ${ }^{9}$. Frustasi itu diakibatkan dari pengenalan seseorang terhadap keadaan dan situasi lingkungannya. Tidak berarti frustasi itu terjadi pada seseorang saja, tapi pengenalan orang terhadap situasi yang menekan, sangat tergantung pada kepercayaan terhadap dirinya dan pengenalan itu terpengaruh oleh lingkungan sekitarnya. Jadi seseorang yang mengalami masalah hidup atau kesulitan hidup yang tidak dapat mencapai objek tujuan yang ingin dicapai.

Lingkungan luar tersebut mencakup sumber-sumber alam sekitar, termasuk faktor ekonomi, sosial, perundang-undangan dan segala sesuatu yang meliputi manusia. Penyebab timbulnya frustasi adalah :

- Frustasi lingkungan yaitu frustasi yang disebabkan oleh rintangan yang terdapat dalam lingkungan sekitar.

- Frustsi pribadi yaitu frustasi yang timbul karena perbedaan antara kemampuan dan keinginan, atau ada perbedaan antara ideal self dengan real self

- Frustasi konflik yaitu frustasi yang disebabkan konflik dari berbagai motif dalam diri seseorang.

9 Robert H Thoules, Psychologi of Religius diterjemahkan Machmun Husein, ( Jakarta: Raja Grafindo Persada), 1995), hlm. 74. 


\section{Stres}

Stres adalah suatu gangguan pada tubuh dan pikiran yang disebabkan oleh perubahan dan tuntutan kehidupan, serta dipengaruhi oleh lingkungan maupun penampilan individu dalam lingkungan tersebut. Stres sebagai gejala yang timbul akibat adanya kesenjangan antara realita, antara keinginan dan kenyataan, antara tantangan dan kemampuan, antara peluang dan potensi, ${ }^{10}$ Penyebab stress dapat mengakibatkan terganggunya kekebalan tubuh terhadap penyakit ringan seperti flu, infeksi, tekanan darah tinggi, sakit kepala, diare, gangguan pencernaan serta penyakit lainnya, karena itu setiap insane bertanggung jawab sepenuhnya terhadap stress.

\section{Cemas}

Cemas merupakan bentuk lahir dari proses emosi yang bercampur baur yang terjadi ketika terjadinya frustasi dan konplik seperti takut, ngeri, rasa lelah, rasa berdosa, rasa terancam terus, cemas. Seseorang merasa takut tanpa mengetahui faktor-faktor yang mendorong keadaan tersebut.

- Cemas ini terdiri dari :

Cemas objektif, yaitu sumber cemas objektif berasal dari luar diri seseorang. Cemas objektif adalah reaksi terhadap pengenalan akan adanya bahaya yang disangkakannya akan terjadi.

- Cemas Penyakit

Cemas penyakit ini dibagi atas tiga bagian yaitu cemas umum, cemas individu, dimana seseorang merasa takut yang samar dan umum serta tidak menentu. Cemas penyakit ini mencakup pengenalan terhadap objek atau situasi tertentu. Cemas penyakit ini mencakup pengenaalan terhadap objek atau situasi tertentu. Seseorang yang takut melihat darah, cemas dalam bentuk seperti ini adalah bentuk cemas yang menyertai gejala gangguan kejiwaan seperti hysteria.

- Cemas Moral

Cemas Moral ini timbul akibat tekanan dari dorongan zatnya tinggi, rasa dosa, seperti keadaan cemas penyakit dapat terjadi dalam berbagai bentuk, yakni: 1). Gejala jasmani, yaitu ujung-ujung anggota tubuh dingin, tidur terganggu, keringat banyak, dan kepala terasa pusing.2). Gejala kejiwaan antara lain: sangat takut akan terjadi bahaya, dan selalu merasa akan terjadi.

\section{Munculnya Aliran Sesat seperti Syiah.}

Perhatian masyarakat terhadap kegiatan keagamaan memberikan pengaruh terhadap kegiatan keagamaan.Abu Ahmadi mengungkapkan bahwa manusia adalah makhluk sosial dan hidup di tengah-tengah masyarakat. Di lingkungan masyarakat terjadi hubugan satu

\footnotetext{
${ }^{10}$ Dadang Hawari, Psikiater, Terjemah Al Quran, ( Yogyakarta: Dna Bakti Primayasa, 1997), hlm. 171.
} 
sama lain dalam bentuk pergaulan masing-masing saling berintekrasi, saling give and take, bahkan berhubungan dengan lingkungannya ${ }^{11}$. Jadi apabila tokoh masyarakat mempunyai perhatian yang baik terhadap kegiatan keagamaan, maka besar kemungkinan masyarakat yang ada di lingkungan tersebut terpengaruh dengan adanya aliran tersebut di sekitar lingkungannya.

Memahami pergerakan Syiah di Indonesia tidak terpisah dari dinamika perkembangan syiah di seluruh dunia. Ditinjau dari perjalanan sejarah komunitas syiah di Indonesia dapat dikategorikan dalam tiga generasi utama, yaitu generasi pertama, yaitu sebelum meletus Revolui Iran tahun 1979 syiah sudah ada di Indonsia baik Imamiyah, Zaidiyah, maupun Ismailiyah ${ }^{12}$. Mereka menyimpan keyakinan itu hanya untuk diri mereka sendiri dan untuk keluarga yang sangat terbatas. Karena itu mereka bersikap sangat eklusif, tidak atau belum seperti semangat missionaris untuk menyebarkan ajarannya kepada orang lain. Gagasan tersebut didominasi oleh keluarga intelektual, kebanyakan beasal dari perguruan tinggi. Mereka tertarik kepada kepada syiah dari pada ritus-ritus atau fighnya. Dari segi struktur sosial, generasi ini berasal dari kelompok menengah ke atas, kebanyakan mahasiswa dan akademik perguruan tinggi. Dari segi mobilitas, banyak diantara mereka yang punya akses kepada hubungan Islam Internasional. Dari segi idiologi, cenderung radikal, lebih mirip dengan pedoman diri, kelompok Neo Marxian. Gerakan ini banyak yang membuat gangguan kepada masyarakat karena gerakannya agak berbeda dengan gerakan agama resmi di Indonesia. Kehadiran mereka di tengah-tengah masyarakat dapat meresahkan, karena paham ini mencoba membuat gerakan yang mirip dengan sebahagian gerakan umat Islam, seperti memiliki mesjid, teapi tidak sama dengan mesjid umat Islam.

\section{Keberadaan Lingkungan Sosial}

Lingkungan sosial merupakan bagian yang tidak terpisahkan dari kehidupan manusia. Dengan demikian lingkungan sosial adalah masyarakat serta berbagai system norma yang terdapat di sekitar individu atau kelompok manusia yang mempengaruhi tingkah laku mereka dan interaksi di antara mereka ${ }^{13}$.

Pergaulan hidup manusia diatur oleh berbagai macam kadah norma, yang pada hakikatnya bertujuan untuk menghasilkan kehiupan bersama yang tertib dan tenteram. Tetapi lingkungan tempat tingal sering memberikan pengaruh besar, utamanya terhadap kehidupan remaja. Lingkungan orang yang berandalan akan mempengaruhi mental masyarakat yang berada di sekitarnya. Karena di dalam lingkungan sosial itu terdapat teman bergaul yang tidak dapat dipisahkan dari kehidupan. Teman bergaul yang besar

\footnotetext{
${ }_{11}$ Abu Ahmadi, Ilmu Pendidikan Islam, ( Jakarta: Rineka Cipta, 1991), hlm. 85.

12 Tim Penulis MUI Pusat, Mengenal dan Mewaspadai Penyimpangan syiah di Indonesia., ( Jakarta: Oll Rghts), hlm.. 93

${ }^{13}$ Tim Penyusun Kamus Pusat Pembinaan Bahasa Depdiknas, Kamus Besar Bahasa Indonesia, ( Jakarta: Balai Pustaka, 2005), hlm. 675.
} 
pengaruhnya adalah teman sebaya, pergaulan yang besar pengaruhnya adalah terutama pada remaja. Elisabeth B. Hurlock yang mengatakan remaja biasanya mempunyai dua atau tiga orang teman dekat atau teman bergaul. Mereka adalah sesama seks yang mempunyai minat yang sama dan kemampuan yang sama. Teman dekat saling mempengaruhi satu sama lain meskipun kadang-kadang juga bertengkar ${ }^{14}$. Jadi teman bergaul dalam lingkungan social dapat memberikan pengaruh baik dan buruk terhadap kehidupan remaja. Dengan demikian remaja harus mampu memilih teman yaitu teman yang mampu memberikan pengaruh positif terhadap dirinya. Demikian halnya pada anak anak, dimana lingkungan besar penaruhnya terhadap pergaulan anak-anak, bahkan juga berpengaruh pada orang tua.

Dengan demikian orang tua harus memantau pergaulan anak, karena apabila anak salah dalam memilih teman bargaul maka akan membuat kepribadiannya kurang bagus.

Dalam kehidupan keberagamaan banyak mendapat gangguan-gangguan. Gangguan tersebut diakibatkan oleh beberapa faktor yang mempengaruhi gangguan jiwa keagamaan.

\section{Faktor Intern}

Faktor intern yang mempengaruhi jiwa keberagamaan adalah menyangkut factor:

\section{Hereditas}

Hereditas yakni menyangkut sifat yang diwarskan atau sifat turun temurun jalaluddin mengutip hasil penelitian yang mengatakan bahwa DNA berbentuk tangga berpilin terdiri atas pembawa sifat yang berisi informasi genetic. Pembawa sifat keturunan itu disebut genotif dan Fenitif Dimana genotif adalah keseluruhan factor bawaan seseorang yang dimungkinkan dapat dipengaruhi lingkungan, namun tidak jauh menyimpang dari sifat yang ada. Sedangkan fenotif aalah karakteristik seeorang yang tampak dan dapat iukur seperti warna mata, warna kulit15. Jadi factor hereditas merupakan keseluruhan factor bawaan yang dimiliki oleh setiap individu. Faktor hereditas ini menurut Sigmund Freud muncul akibat adanya rasa bersalah yang dlakukan oleh seseorang. Bila ada pelanggaran yang dilakukan terhadap larangan agama, maka akan timbul rasa berdosa. Dan perasaan inilah yang menjadi gangguan dalam perkembangan jiwa keberagamaan 16 .

Jiwa keagamaan memang bukan yang diwariskan secara langsung sebagai factor kejiwaan yang diwariskan turun temurun, melainkan berbentuk unsur kejiwaan yang diwariskan turun temurun. Tetapi dari faktor DNA ini banyak sekali orang yang mendapatkan gangguan dengan sifat-sifat yang iturunkan dari orang tuanya. Dimana perilaku orang tua yang tidak baik bisa saja diturunkan pada anak - anaknya. Hal tersebut akan menjadi ganguan sosil terhadap kehidupan anak-anaknya.

${ }^{14}$ Elizabeth B. Hurlock, Psikologi Perkembangan Suatu Pendekatan Sepanjang Rentang Kehidupan , ( Jakarta: Erlangga, 1980), hlm. 215.

${ }^{15}$ Jalaluddin, Psikologi Agama, ( Jakarta: PT. Raja Grafindo Persada, 2007), hlm. 211.

16 Ibid, hlm. 215. 


\section{Tingkat Usia}

Tingkat usia yang merupakan hal yang menganggu terhadap jiwa keberagamaan manusia. Dalam perkembangan tersebut dipengaruhi aspek kejiwaaan, dan juga tingkat berfikir. dimana anak yang mulai mengnjak masa remaja akan berfikir lebih kritis terhadap ajaran agama. Sehingga pada usia ini ada keraguan para remaja terhadap ajaran agama, dimana mereka ragu antara ingin melaksanakan ajaran agama dengan ingin menuruti masa panca roba dengan mulai daangnya masa puberitas. Tingkat perkembangan usia dan kondisi yang dialami remaja ini menimbulkan konflik kejiwaan, yang cenderung mempengaruhi terjadinya konversi agama. Menurut Ramayulis bahwa hubungan antara perkembangan usia dan jiwa keagamaan tidak dapat dihilangkan bagitu saja. Meskipun tingkat usia bukan merupakan satu-satunya factor penentu dalam perkembangan jiwa keagamaan seseorang, tetapi kenyataan dapat dilihat dari adanya perbedaan pemahaman pada tingkat usia yang berbeda ${ }^{17}$. Dimana dengan perbedaan tingkat usia ada perkembangan yang menonjol yang berbeda dengan perkembangan jiwa beragama pada usia sebelumnya.

\section{KEPRIBADIAN}

Kepribadian menurut psikologi terdiri dari dua unsur, yaitu hereditas dan pengaruh lingkungan. Hubungan antara kedua unsur tersebut yang embentuk kepribadian, sehingga menyebabkan munculnya konsep tipologi dan karakter. Tipologi penekanannya cenderung kepada unsure bawaan, sedangkan karakter lebih mengarah pada pengaruh lingkungan ${ }^{18}$.

Tipologi manusia sebenarnya memiliki kepribadian yang unik dan bersipat individu yang masing-masing berbeda. Dengan perbedaan kepribadian itulah manusia memiliki berbagai tipe yang terkadang menjadi gangguan dalam penyesuaian diri.

\section{PENUTUP}

Dalam kehidupan manusia bukan saja gangguan social yang terjadi, tetapi juga terjadi gangguan terhadap jiwa keagamaan . Manusia sebagai penerima gangguan tersebut harus berusaha untuk mencari solusi ganguan yang dihadapinya . Terjadinya gangguan sosial dalam kehidupan manusia bukan saja secara intern tetapi juga secara ekstern. Manusia yang beriman akan menghadapi gangguan dengan kesabaran dan menjadikan keimanannya akan bertambah, sedangkan bagi orang yang tipis rasa keimanannya maka banyak yang mengalami stress dalam mencari solusinya, bahkan yang paling fatal sering terjadi pindah agama .

\footnotetext{
${ }^{17}$ Jalaluddin dan Ramayulis, pengantar Ilmu Jiwa Agama, ( Jakarta: Kalam Mulia, 1989), hlm. 34

${ }^{18}$ Ibid, hlm. 231.
} 


\section{DAFTAR PUSTAKA}

Abu Ahmadi, Ilmu Pendidikan Islam, Jakarta: Rineka Cipta, 1991.

Aini Mahabbati, Gangguan Sosial, Bandung: Angkasa, 2006.

Jalaluddin, Psikologi Agama, Jakarta: PT. Raja Grafindo Persada, 2007.

Dadang Hawari, dan Psikiater, Terjemah Al Quran, Yogyakarta: Dna Bakti Primayasa, 1997.

Elfindri, Ekonomi Ketenaga Kerjaan, Padang: Andalas University Press, 2004.

Elizabeth B. Hurlock, Psikologi Perkembangan Suatu Pendekatan Sepanjang Rentang Kehidupan, Jakarta: Erlangga, 1980.

Ramayulis,. Pengantar Ilmu Jiwa Agama, Jakarta: Kalam Mulia, 1989.

Robert H Thoules, Psychologi of Religius diterjemahkan Machmun Husein, Jakarta: Raja Grafindo Persada, 1995.

Sajogyo, Pembangunan Daerah dan Pemberdayaan Masyarakat, Jakarta: Bina Rena Pariwara, 1997.

Sri Edi Swasono, dkk, Kemiskinan dan Keadilan, Universitas Indonesia, Jakarta: Departemen Agama RI, 1989.

Soetomo, Masalah Sosial Dan Pembangunan, Jakarta: Pustaka Jaya, 1995.

Syekh Muhammad Yusuf Al Qordhowi, Problema Kemiskinan Apa Konsep Islam, Surabaya: Gema Insani Press, 1982. 
FITRAH Vol.01 No.2 Juli-Desember 2015

Tarawih Dan Tahajjud

(Tinjauan Persamaan Dan Perbedaan Dalam Pelaksanaan Dan Keutamaan) 